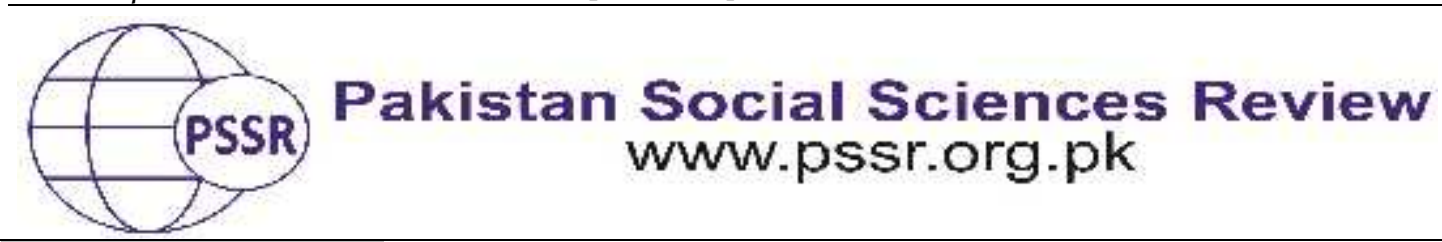

RESEARCH PAPER

\title{
Impact of Climate Change on Aquatic Situation in India: Implications for Pakistan
}

\author{
Dr. Iram Khalid ${ }^{1}$ Tahira Mumtaz ${ }^{2}$
}

1. Chairperson, Department of Political Science, University of the Punjab, Lahore, Punjab Pakistan

2. Ph. D Scholar, Department of Political Science, University of the Punjab, Lahore, Punjab Pakistan

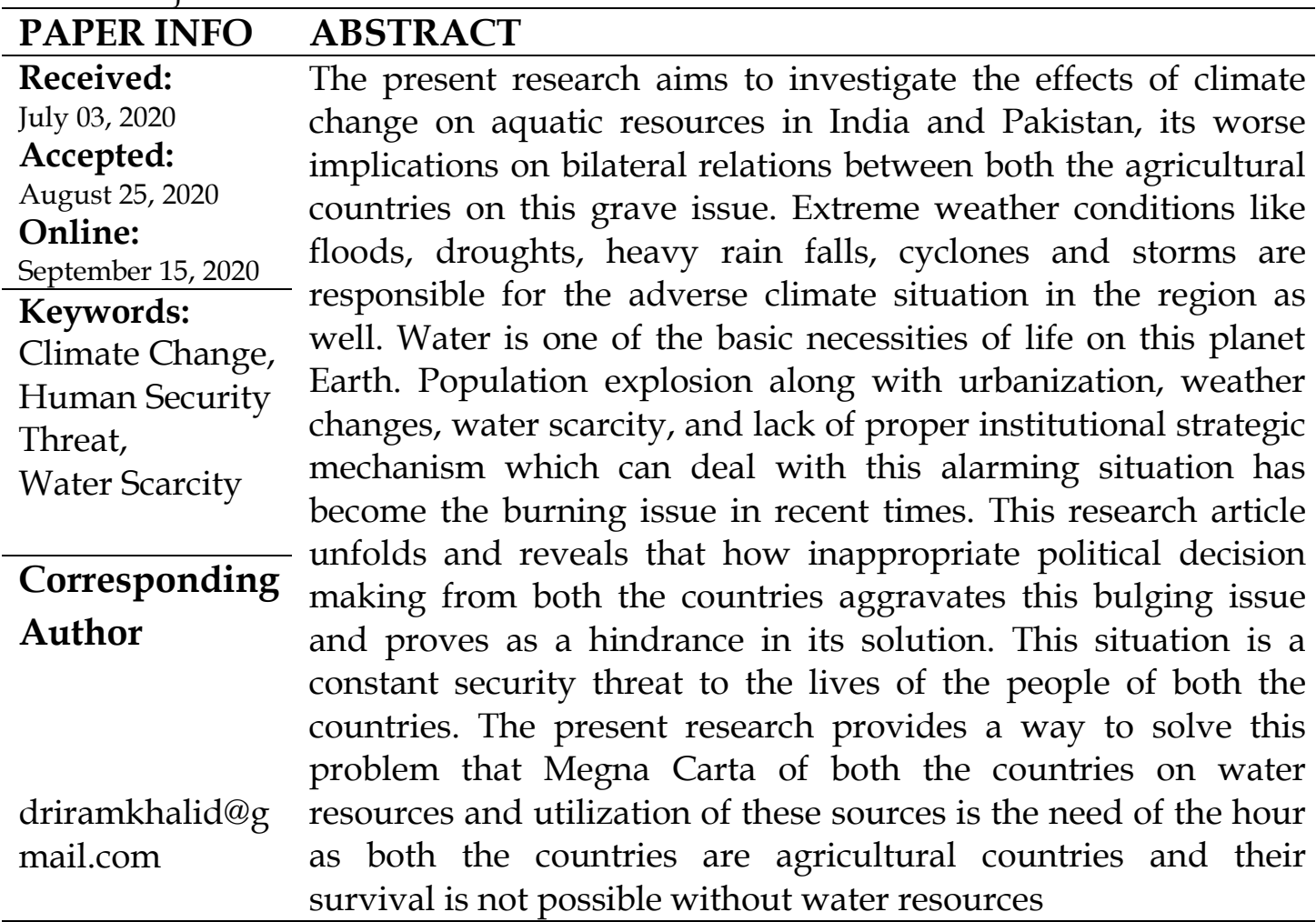

Introduction

Water is an essential substance for life and it is extensively used to cater the needs of the people. Life is not possible without water. It has its vital role in the world economy as well. Water has been the cause of political inclinations and disputes since the creation of many countries like Pakistan and India. These countries were on the verge of war for many a times because of this heated issue. Water along with the symbol of life is also considered as purifying and purging agent and purge the needs of all the living beings. Water is opposing element of fire and air in Europe, fire, metal and wood in China, whereas in the Japanese belief, considering it as contradiction of fire, air and thunder (Prokurat \& Sergiusz, 2015). 
It signifies life, opulence, triumph and the amount and nature of accessible water points out financial progression, wellbeing, the security of inhabitants. Besides if we ponder on the terrains in flooding hazards, the natural territory's condition and enhancement of non-production schemes including the travel industry and facilitation are at risk. Water inefficiency as an impact of climate variation is not the only aspect causing depletion of water resources in these settlements. Aquatic shortage has been tempted not only by increasing demand but also by diminishing water supply. Economic expansion as a driver has not been operative in inducing holistic adaptive response to water scarcity. Climate change considerations have been largely absent in the policy/planning procedures that administer water management in India. The importance of this resource in every field of life is undenied, there are some aspects that are influenced on water scarceness e.g. rising population, industrialization and mismanagement of water resources.

Many experts have focused their attention on energy policy and Green House Gas emissions (GHG). While, ignoring the implications of the changing patterns and ensuing water risks and water scarcities have bad effects on the population of India. Effects of climate variation on aquatic resources have triggered factual exploitation of water resources and these factors are the real causes of severe weather changing conditions, floods and diminishing ice-cover that are considered as climate change. The recent research works show increased droughts causing high temperature, changing precipitation level and disappearing glaciers.

This exploration intends the radical, natural and human glitches allied with aquatic insufficiency in Asia, including parched seasons and the fiscal conditions that are triggered by aquatic insufficiencies. Access of water consumption is a widereaching pecuniary and political test and it is expected to retain converging on substantial matter for some states inthe light of the fact that in the coming years we will face intensifying water necessity, akin to statistic development. Water will turn into an inexorably vital asset, predominantly in Asia. It is foretold that when there will be no accomplishment of demand of drinking water and requisite water will be inaccessible then there will be rise of conflict on aquatic resources or reservoirs.

In Asia, there are no specific assessments of the negative effects of waterrelated issues for economies. There is a requirement to make gradually meticulous computations and alternative progressions of action. For this motive, such measures ought to be reserved in Asian states. India is one of the water-accentuated states and is supposed to become water threatened in due course. Regrettably, the water shortage gets stressed more by its disorganized use than by its physical availability. It is alarming that population increase causing the shortage of significant and unrelenting efforts to upgrade water use competencies; this has become a foremost instinct of aquatic constraints in the country. Increases in population, in the absence of serious and sustained efforts to improve water uses are the reasons of water shortage. The inadvertent dissemination of water is makes it a scarce commodity. This demand for instant consideration by the stakeholders not only to address the 
water problems but also to ensure the availability of water reserves for a better life style.

\section{Climate change and South Asia}

Our world has been facing global warming and climate changes for the last 15 years (Sathaye, 2007). In the long run, climate change is considered as one of the deadliest challenges in South Asia. Stern (2006) discussed in his report that it is going to be too late to take collective actions for handling the future situation of changing climate and to avoid bad impacts in near future that is alarming for the entire region. This report indicates that climate change will affect other elements which are affecting the human life i.e. food, water, health facilities and quality of environment. Due to this change millions of the people will suffer from hunger, no provision of basic human needs, shortage of drinking water; for irrigation purposes, industrial and domestic purposes etc. Human life of this region will suffer badly and unforeseen disasters and other incidences such as floods, storms, droughts, melting of glaciers and cyclones would be expected. Weather changes will affect on agricultural parts due to shortages of water and will be the cause of economic deficit. The Researchers are of the opinion that the change in international environment will certainly increase the temperature of South Asian region that will carry hopelessness to a large number of the people. Indeed, even a minimal change in the temperature may cause a ruinous circumstance for the locale of the region. On the other hand, it will likewise influence the human economic conditions and opportunities for employments and living standards. Other than harming financial interests for millions the other most terrible impact will be the convergence of 'climate refugees' to other over-loaded territories of South Asia which will likewise risk the financial, social and biological equalization of the region. South Asian states are consistently encountering different signs of environmental change from the last couple of years, this cause wrecking floods, violent winds and rainstorms, dry seasons, changes in the timing of rainstorm season and anomalies in precipitation designs. Numerous frequencies in the ongoing years can be referred to build up why environmental change is a significant issue for South Asia.

\section{Changing Water Situation due to Climate Change}

The prominent effect of climate change on irrigation infrastructure is similarly important to consider. Within the hydrological cycle the groundwater processes are expected to have an effect on recharge shifts that include precipitation and evapo-transpiration adjustments, possible changes in the disposition of groundwater and surface water connections, and irrigation-related changes in use (Desai, 2016). There will be a far-reaching effect on industry with water shortage and reduced water quality. Decrease in water supply, tighter regulations, increased cost of freshwater, increasing criticism from the population and increased public awareness of water policies are already being identified (Jain and Singh, 2018). The assumption that climate change creates circumstances far outside of the conventional boundaries of current and future preparation will no doubt be manageable. The 
research provides a detailed description of researches conducted to explain the effects of climate change on water resources (Pathak et al. 2014). Water is a necessary commodity which serves all aspects of the climate system, i.e. the environment, the hydrosphere, the cryosphere, the ground layer and the biosphere (Colopy, 2012). The hydrologic cycle is affected by changes in precipitation, intensity and extreme conditions, widespread snow and ice melting, an increase of water vapour, an increase in evaporation and soil moisture and run-off changes. Climate change is a key issue to be discussed in Himalayas and the Indian Ocean, as the Indus water Treaty cannot address this issue. The flow of water in Indus is increasing every year. At a time when water shortage is captivating in South Asia, water management policies and cooperation frameworks between Pakistan and India are needed.

During the period 1951 to 2014 the average yearly temperature in India was around $25,06^{\circ} \mathrm{C}$ while the mean temperature in the last 15 years (2000 to 2014) increased by around $0,25^{\circ} \mathrm{C}$ compared to 1951 to 2014 . In the last 15 years (20002014), respectively the average high and the mean minimum temperatures have risen to about $0.28^{\circ} \mathrm{C}$ and $0.22^{\circ} \mathrm{C}$ (Jain \& Singh, 2018). While India's maximum freshwater capacity is $1.91 \mathrm{~km} 3=y e a r$, India's per capita water availability is ranked at 132 having 17.2 per cent of the global population (Rao, 2018). The water resources are unevenly distributed spatially, for e.g. in the north-east of the country, water per capita is available in the Brahmaputra basin at $17000 \mathrm{~m} 3$, whereas the Sabarmati basin at Sabarmati is $240 \mathrm{~m} 3$ (Rao, 2018). A strongly considered alternative to alleviate the reduced water availability in some southern States is the potential for water transfer between river basins. The primary purpose here is that water is diverted to the water scarce north, western and southern parts of the rivers Ganga, Brahmaputra and Godavari. In several areas of the country, the effects of climate change are anticipated to increase (Desai, 2016). Design and maintenance of water resources, including hydrological systems, flood and drought control and community planning and development will be affected by fluctuations in rainfall. India's agricultural economy is particularly liable to expected climate change and relies heavily on the monsoon and irrigation for growth (Salve, 2017). Therefore, better assessment of the impacts of climate change and the implementation of strategies utilizing future scenarios is important. The existing systems with water resources have some important data gaps including processing, monitoring, dissemination, communication gaps, storing of water networks and cannot address the anticipated challenges of a climate that is rapidly changing (Anjal Prakash. Saravanan \& Chourey, 2012).

\section{Effect of Climate Change in India}

Climate variation is a major challenge in India for 1.2 billion citizens in the 21st century with regards to health, food safety and the welfare of people. In several parts of India, from the dry north-west where precipitation is low, to the maximum rainfall area in the north-east; there is a skewed geographical distribution of water resources. India's weather has reached the extremes over the past few decades and it 
has been catastrophic (Prokurat \& Sergiusz, 2015). For example, the famine of 2016 occurred in about 10 states and effected nearly 330 million people that resulted in a financial loss of INR100 million. Climate change affects water resources in river basins through weather temperature, rain and irrigation (Pathak et al. 2014). The research studies which are used to collect the daily weather data from the Indian Meteorological Department (IMD) and HadRM2 to predict the components of water balance. As rain gage stations are unavailable and long-term historical rainfall information in the catchment areas are available, temperature trends are more realistic than yields of water. Research on climate change related to basin-specific supply of water resources suggests that environmental change is possible to affect the hydrological cycle in:

- Increased rain in much less time-frame;

- $\quad$ less rainy days;

- $\quad$ more precipitation overall;

- $\quad$ More initial glacial melting and eventual decline;

- $\quad$ More running but less terrestrial recharge;

- $\quad$ Rise in occurrences of flash floods;

- Increase in situations similar to droughts;

- $\quad$ An increase in the chances of landslide in hiSorapipatana lly areas and other associated issues, etc.

Climate change has a variety of mechanisms. Due to the change in weather patterns in some parts of India, particularly North and North West, there will be a significant shortage of drinking water (Pongthanaisawan, 2013). After the Arctic and the Antarctic Ice caps, the Himalaya region is the third main area in the world, with a noticeable increase in the snow melt, and if this occurs, the water supply in much of Asia will be affected. In many regions of the world, water is already overappropriated. In water-stressed nations, more than one quarter of the worlds peopleapproximately 2.4 billion residents-live and are expected to grow to two thirds by 2025. In various parts of the world, the utilisation of human resources lowers ground water sources and lake flows (Desai, 2016). For example, farmers in India now use almost $80 \%$ of the country's available water, primarily from groundwater wells; at current levels, the World Bank predicts that Indian water supplies will be drained by 2050 (Scheuring \& Engelbert, 2002). A study of the IPCC Fifth Assessment Reports the climate change message, temperatures in South Asia, with trillions of people directly affected, especially in relation to heat events. Climate and development knowledge network (CDKN) Challenges to glacier melt water resources are even stronger than historically expected: a bleak image of high-temperature rise in the 
upper reaches of the Hindu Kush mountain range can be seen with new modelling scenarios (Colopy, 2012).

\section{Water Sharing Problem between India and Pakistan}

Water sharing remained a current issue, despite the fact that the Indus Water Treaty, established between India and Pakistan decades ago, it had a remarkable precedent whose significance has yet to be repeated in any domain between the two states since then (Pathak et al. 2014). This is also the reason that there was a security problem surrounding water use and water resources. In recent years, however, water has become a popular point of discussion in Pakistan due to the increased water scarcity and the condition has contributed to political, ethical and regional debates in South Asia, as water has now become a significant point of debate. Pakistan was the natural claimant due to the lower riparian during this dispute (Desai, 2016). Just as terrorism and Kashmir issue are the unfinished points of contention, the water dispute has now developed a similar position. The problem of rivers flowing from Indian controlled state Kashmir to Pakistan was a late flash point between two nuclear neighbours who have waged almost four wars since their independence (Scheuring \& Engelbert, 2002).

\section{Challenges}

- $\quad$ Existing water challenge due to unsustainable supply and impact of climatic changes on water stressed areas.

- Climatic variations in lieu of melting glaciers and snow-capped mountains subsequently reducing the water availability.

- $\quad$ Due to inadequate precipitation level and rainfall ratio in different areas causes water shortage.

- Increase in temperatureis engendering severe weather events and long droughts

- Insufficient aquatic basins are the root cause of more flooding in several terrains

- $\quad$ Severe weather conditions arecreating alarming water demand

- Quantitative/Qualitative supply of water needed direly for industrial use

- According to climate model analysis, many people are in danger due to scarcity that is increasing with high temperatures in the area. Effects of climate change are expected much larger than the international surveys and reports. (IPCC, 2001, Parry et al. 2001).

\section{Water Resources}

Water is a natural resource which has immense value around the world. It is a resource that not only quenches thirst but is used for essential daily activities (Hall, Van Koppen \& Van Houweling, 2014). Water resources are widespread available around the world in different forms. In accordance to US Government (2019) the 
Earth has 71 percent of water against the 29 percent of land which is a proof that water is readily available. Water is a renewable resource which means that it will not replenish no matter how much it is used; however major concern is that water on the earth is divided in to fresh and salt water. Out of 100 percent of water roughly 3 percent is available which is less for the increasing population of the world is significantly. Salt water is available at oceans and seas while fresh water sources are rivers, lakes and glaciers. In accordance to Verma and Sengupta (2019) India receives fresh water from rivers which are Ganges, Yamuna, Indus and Brahmaputra that originate from the melting glaciers in Himalayan Mountains. There are other sources such as ground water and lakes which provide fresh water to the country.

The rising population has set an alarming situation for the modern climate situation. In this modern era the world experiences such drastic climate changes which are responsible for human and natural destruction (Chakravarty et al. 2012). As years and decades pass by, the global temperature rises which are a result of negligence shown by humans towards the climate and overuse of technology such as motor vehicles using conventional which emit greenhouse gasses (Pongthanaisawan and Sorapipatana, 2013). Greenhouse gasses are one of the major contributors to drastic climatic changes which are responsible for the melting of the mountainous glaciers those results in overflowing of rivers and floods on the mainland. Deforestation is renowned to be another contributor to the climate since trees are essential for maintaining of the environmental temperature (Lynch et al. 2013). The rise in temperatures has eventually led to the melting of the polar glaciers which increases the risk of the reduction of fresh water and enhances the sea water level.

\section{Causes of Water Shortage}

India is the populous states in the world where 63 million people do not have access to fresh drinking water (Salve, 2017). It is estimated that both natural and man-made causes are the main reasons for the shortage of water in the country. The administration fails to inoculate the water reserves which lead to increase water contamination likely results in threatening human life. In accordance to Reuters (2019) the Ganges River of India where people frequently bathe and wash their clothes has been contaminated and it has become undrinkable. The government of India has also forecasted that soon the country will no longer be able to obtain water from its groundwater reserves due to excessive utilisation (Chandran, 2019). Being a country, which generates heavy revenues from the agricultural industry, an excessive amount of water is required to grow crops and feed the rising population (Gabbatiss, 2018). It is however important to highlight that it is the rising population which is responsible for the inadequacy of water in the country and government must take measures to overcome it.

Pakistan has been facing similar but a bit different water crisis situation than India. The Indus Water Treaty that had been signed between both states let India control the water flow to Pakistan and it was to be shared amid the two countries (Kokab and Nawaz, 2013). The flowing water had to be used for irrigation of crops, 
energy and domestic consumption; it had proved to be of immense value. Giving India the upper hand to control the flow of water allowed it to exploit the terms of the treaty and would restrict the water flow causing shortage in the Pakistan (Kalair et al. 2019). As per the study of Haider and Adnan (2014) another reason for the shortage of water is the lack of rainfall and the ability to store water in rainy seasons in reservoirs. Lack of rainfall resulting from excessive deforestation has caused droughts in many areas of the countries and has wasted farmlands.

\section{Water Scarcity and Human Security}

Water is an essential mineral for human beings. In order to sustain their very existence human have rely on water for multiple reasons. One of the reasons is highlighted by Paglia (2018) who has stated that water is part of a healthy diet and if water is not consumed it would result in fatal diseases. Humans require a steady supply of water and scarcity of water can be an obstruction in their daily lives (Dinka, 2018). Not particularly humans but animals require water for survival. Many industries such as the food and beverages require water for the production of their materials. The agricultural industry would strive the most with water scarcity since crops such as wheat and rice require excessive water supply to grow (Gabbatiss, 2018). Water is a vital element that has been bestowed by nature and measures must be taken for not wasting the resource.

\section{Natural and man-made causes of water shortages:}

The dangers and threats related to dry seasons and water shortages are persistent because of these reasons: Natural reasons: Extreme hydrological marvels droughts and floods - have turned into a severe issue in many areas of the world. Floods kill many people every year particularly in India. Such an overflow of water incomprehensibly causes lack of drinking water that is the natural disaster which is very hard to face. In the meantime, shortage of water, known as an absence of water, is a disastrous event. Its immediate reason is an absence of rainfall. Around 20-30 days without rain is sufficient to observe the drying out of soils and mass deaths of plants, and every day which goes without rain will just increase the size of the death rate - mass moves of animals, soil desertification, starvation, and a profoundly extended likelihood of disastrous fires. If such conditions are kept up for over a month, we can say that the natural disaster is in fact a drought. The impact of dry seasons and water scarcity are divided into these categories: natural, economic and societal consequences. Due to environmental effects: lower and subversive levels of water, lower flow, lingering water pollution, the lands are drying out, more fires, higher deflation, more awful position of trees. Financial deficits incorporate lower agrarian, timberland and fishing profit, higher nutrition manufacturing prices, lesser energy generation stages in hydro plants, shortage brought about by drained water, the travel industry and transportation income, problems with supply of water for the power sector and innovative measures in the chemical, paper, timber, food enterprises, metallurgy, interruption of water provisions for city economies. In the meantime, societal costs are directly affected on the individuals and also have worst 
effects on the wellbeing of the people, reasonable limit of water provisions and its high food prices, tension brought about by wrecked crops and so on. That is why dry areas and water shortages might be treated as an issue which brings the gap among developed and developing states.

Man-made dangers: Intensive civilization progress and statistical development have prompted negative changes of the scene because of human movement. The speedy changes in land use, with the substitution of stable biological systems, for example, woods, meadows and wetlands into ecosystem, specifically agrarian fields. This has prompted fast and negative changes in the warmth and water balance of the whole state. Besides this a developing population around the world, which is an immediate factor behind more water systems, the worldwide water scarcity is also brought about by our activities, particularly by emerging demand for meat, because more amount of water is required for meat items when contrasted with vegetables. The proportion of this growth is due to water, which depicts the whole measure of drinking water used to produce a given good (additionally in a roundabout way, for example with the utilization of water system). Unless the population has no easy access to drinking water, no change can be seen in the name of development. Water related issues are not handled seriously in India. Extremely agricultural areas are affected by environmental change. AnIncrease in the number of pests and diseases are the main cause of the die-offs of young trees that are triggered by droughts. Changes in climate and water shortage cause danger to weather fluctuations that are risky at commercial level.

\section{Gap between Policy Making and Policy Implementation/ Enforcement}

India's many parts face water scarcity. There are common causes of this problem and it's obvious that there is a lack of domestic policy to address this problem seriously. Water scarcity is a major risk for development because India has most of its area that is agricultural. It is the need of the hour that policy makers should take bold decisions to resolve this problem. If agricultural land is facing water scarcity then other developments could be stuck down because all developments are interlinked with each other in different ways. It is the responsibility of the diplomats to focus on water sustainability and reshape this understanding not only with the partners but also with all policy makers. The Secretary has the authority to mobilize state leaders and make some decisions to solve this problem. The Secretary has the opportunity to present these case studies in the environmental sector that this sector has distinguished position and is a form of development in India. India is facing a threat of a water crisis. The World Bank reported that "by 2050, demand of Indian water will surpass all accessible sources of supply". (Malik, 2008) 90 percent of the wells have been dried up that are owned by local farmers. In the last decade, half of the irrigation area has been reduced and water tables have fallen down in this time frame. (Brown, 2004). Increasing threat of groundwater is due to overpopulation, industrialization, pollution and lack of proper management. At present, water policy debate has been extended due to privatization of urban water, approaches to economic management and 
decentralization of irrigation systems. The main problem of policy statements is that they have not been seen in practice. There is no financial support for implementation of these policy statements. It is also observed in different cases that there is clear contradiction between policies and water laws. Most importantly, national policy is not the reflection of the state water policy and national action plans. Groundwater planning, proper water distribution and management of surface is totally ignored. (Wood, 1998) It is a desperate need to update water reforms, legislation and institutional arrangements in India. Many environmental laws are neither existent nor implemented. Even so, a huge gap is seen between state and governmental institutions. Lack of coordination is seen for water management and for resolution of this conflict. (Wood, 1998)

The National Ministry of Water Resources is facing trans- boundary problems. Previous minister called himself "Minister of Water conflicts". Economic journal shows that some case studies from India prove that there is no good record of interstate agreements of water conflicts. (K.J. Joy, 2009) For instance, India has not respected Indus Water Treaty by building up the hydro project of 'Baglihar' by discussing it a democratic success but India's attitude is "not good in bilateral framework" (Sinha, 2006) Another case study is based on interstate dispute, in which one party disregards a previous agreement. This SYL canal case study proves that the country faces poor level of adjudication. In all of these case studies, there is dire need of planning, policies implementation and reliance on international institutions to achieve the desired results. Insufficient water supply is the major factor of limiting development of India. Water is also a sign of prosperous and healthy life in any state or area. The key consumers of water are the industrial, agricultural and domestic users. Demand of water is increasing in the agricultural sector but also steadily rising demand of water is also seen in other two sectors i.e. domestic and industrial too. If scientists pay attention to the policy making and exchange ideas to civil society groups and policy makers, it will make more chances of science being useful. Combination of rain water savers, waste water reprocessing, pricing and productivity would be more cost effective than building purification plants.

\section{Impact of Water Shortage on Pakistan}

According to the Indus Water Treaty which is signed amid Pakistan and India, both the countries agreed to share their water bodies; however, India had control of the water supply of most of Pakistan's rivers (Kokab \& Nawaz, 2013). Shortage of water could possibly result in India not supplying much water to Pakistan which could escalate political tensions between the two states. The study of Johnson (2019) has stated that both the countries are close to a water war due to political reasons and shortages of water. Another article DW (2019) has even stated that if Pakistan is unable to receive water it may run dry in the year 2025 which is quite alarming. 


\section{Conclusion}

Water is a vital element of life and plays an important role in anyone's life and development of any state. High population rate, urbanization and lack of water management policies are the main factors which are affecting the water shortage in Pakistan and India. An unattended water problem by policy makers and negligence from all the stakeholders is another reason of water scarcity in both states. No doubt, water is an element which is responsible in destabilising Pakistan. Water is an important substance because of the low quality of water; it is not only affecting the well-being of the people but also on the economy of the country. Water also plays vital role in industries. Practical Strategy of supply and demand of water is required to solve this issue on urgent basis. The need of the hour is that to address water issues, factors working behind the water scarcity, misuse of water resources, a working mechanism to resolve this issue is needed. Delaying tactics to deal this hot issue would be major cause of water insecurity that will exacerbate the situation, could be a full-fledged war over water. Like other developing countries, Pakistan is vulnerable to face the disastrous effects of climate change. Adverse effects of global climate change are due to Green House Gasses (GHG) emissions. Water is adversely affected by climate change that is very harmful for the growing population of Pakistan. Being an agricultural country, it is fully dependant on water. The Prolonged droughts situations, heavy floods and rainfall, hot winter and early summers can lead to the unfavourable economic, social, political and moral conditions in our country Pakistan and can be a great hindrance in the progress and prosperity of our nation. Effects of climate change are considered our bio-diversity, access to safe water, food security, health of the people and overall wellbeing are in danger. Being an upper riparian, India has full control over water and misuses its power against Pakistan. If these issues will linger on and not be addressed practically the situation can be worst. So the need is to take this situation seriously on the basis of mutual understanding otherwise we will have to face the threat of looming war between Pakistan and India.

\section{Suggestions}

Understanding of issue is the first step towards resolution of the problem. Active institutional approach, a practical mechanism to tackle the issue, political and social determination is mandatory to resolve the issue. Water scarcity is an international issue and organizations e.g. United Nations Environmental Program (UNDP) and United Nations Water Division are handling these issues and financing the countries which are unable to resolve these problems on environmental, economic and political grounds. Both states should take steps seriously to resolve the water issue and adopt new strategies and patterns to avoid the severe effects of climate change. A joint policy mechanism is needed on urgent basis and to form a new treaty for Indus waters considering the environmental constraints on water supply and availability. A new joint mechanism must be exchanged in replacement of Indus Water Treaty because with the passage of time, there are changes seen in climate and this Indus water treaty does not address the issue of climate change and 
some other serious challenges i.e. changes in weather conditions, temperature, patterns of rainfall, melting of glaciers is not highlighted. Moreover, serious productive political strategies are needed to resolve this hot issue. Being upper riparian, Indian information must be exchanged with Pakistan so that Pakistan would be able to handle this issue with a practical mechanism. The policy makers of Pakistan should take precautionary measures to avoid floods and water dry. Stakeholders of both states should realize this reality that welfare of the people of South Asia is in the best interest of India and Pakistan. Water storage capacity must be developed to assure that supply of water will be same throughout the year. Public awareness for consuming of water in a proper way is necessary. If masses do not know the value of safe water usage then it is impossible to save and use of these natural resources in a better way. Global adaptation under the United Nations Framework Convention on Climate Change is required. Climate change could be controlled while reducing the dependence on fossil fuels. Shifting from fossil fuels to energy resources such as solar energy and hydropower that do not produce $\mathrm{CO}_{2}$ will help to control change in climate. Human activities are directly affected on Greenhouse gasses, planning in population growth should be considered for the long run. Pakistan has much more problematic situation of water access in both urban and rural areas. It necessitates imperative considerations. The advancement and up gradation of irrigation system is needed to enhance water utilisation on urgent basis. All the stakeholders should show their consent on the issue of Kalabagh Dam that is in the best interest of Pakistan. Besides this, Bhasha and Muhammad dam should be taken as a serious national issue as water is the main factor of prosperous Pakistan. Politicizing the water issue is the criminal act that does not favour the national interest. Research culture and technological development must be promoted in the main areas. Water shortage issue in Pakistan requires political will, vision and applicable political policy making approach.

It is time to think about the water crisis and looming threat of war over water in near future. If we do not take serious decisions and address this hot issue on different forums, a very dreadful and horrible picture of Pakistan is expected from transforming fertile into deserted Pakistan. If we are unable to understand the effects of climate change on water and unable to follow the new techniques to handle the water issue in a practical manner then our future generations will not forgive us for such a criminal negligence on the wastage of natural resources. Both countries are facing with misconception and distrust since partition. It is a dire need to build mutual understanding on solid footings for the welfare of the masses of South Asia. 


\section{References}

Anjal Prakash. Saravanan, V. \& Chourey, J. (2012). Interlacing water and human health. New Delhi: Sage Publications.

Brown, Lester. (2004). Bookstore - Outgrowing the Earth: The Food Security Challenge in an Age of Falling Water Tables and Rising Temperatures. Chapter 6. Stabilizing Water Tables: Falling Water Tables." www.earth-policy.org. 2004. http://www.earth-policy.org/index.php?/books/out/ote6_2 (accessed July 27, 2019).

Chakravarty, S. Ghosh, S. K. Suresh, C. P. Dey, A. N. \& Shukla, G. (2012). Deforestation: causes, effects and control strategies. In Global perspectives on sustainable forest management. Intech Open.

Chandran, R. (2019). U.S. Retrieved 11 October 2019, from https://www.reuters.com/article/us-india-water-lawmaking-analysis/withfees-and-laws-india-rushes-to-save-vanishing-groundwater-idUSKCN1PI183

Colopy, C. (2012). Dirty, sacred rivers. New York: Oxford University Press.

Desai, S. (2016). Snow cover clues to Himalayan climate change. Nature India.

Dinka, M. O. (2018). Safe Drinking Water: Concepts, Benefits, Principles and Standards. Water Challenges of an Urbanizing World, 163.

DW, (2019). Water crisis: Why is Pakistan running dry? | DW | 07.06.2018. DW.COM. Retrieved 11 October 2019, from https://www.dw.com/en/water-crisis-why-ispakistan-running-dry/a-44110280

Gabbatiss, J. (2018). The Independent. Retrieved 11 October 2019, from https://www. independent.co.uk/environment/india-rice-crops-farming agriculture-wheatnutrition-drought-columbia-university-a8431411.html

Goyal, M. K. \& Surampalli, R. Y. (2018). Impact of Climate Change on Water Resources in India. Journal of Environmental Engineering, 144(7), 04018054.

Goyal, Manish \& Surampalli, Rao. (2018). Impact of Climate Change on Water Resources in India. Journal of Environmental Engineering (United States). 144. 10.1061/(ASCE)EE.1943-7870.0001394.

Hedland, I. Heinke, J. Biemans, H. Eisner, S. Flörke, M. Hanasaki, N. \& Stacke, T. (2014). Global water resources affected by human interventions and climate change. Proceedings of the National Academy of Sciences, 111(9), 3251-3256.

Haider, S. \& Adnan, S. (2014). Classification and assessment of aridity over Pakistan provinces (1960-2009). International Journal of Environment, 3(4), 24-35. 
Hall, R. P. Van Koppen, B. \& Van Houweling, E. (2014). The human right to water: the importance of domestic and productive water rights. Science and Engineering Ethics, 20(4), 849-868.

Intergovernmental Panel on Climate Change, IPCC (ed.) (2001) Climate Change 2001: Impact, Adaptation and Vulnerability. Contribution of Working Group II of the Intergovernmental Panel on Climate Change to the Third Assessment Report of IPCC, London: Cambridge University Press.

Islam, A. \& Sikka, A. K. (2010). Climate change and water resources in India: impact assessment and adaptation strategies. In Natural and Anthropogenic Disasters (pp. 386-412). Springer, Dordrecht.

Jain, C. \& Singh, S. (2018). Impact of climate change on the hydrological dynamics of River Ganga, India. Journal of Water and Climate Change, p.jwc2018029.

Johnson, K. (2019). Are India and Pakistan on the Verge of a Water War? Foreign Policy. Retrieved 11 October 2019, from https://foreignpolicy.com/2019/02/25/areindia-and-pakistan-on-the-verge-of-a-water-war-pulwama-kasmir-ravi-indus/

K.J. Joy, Suhas Paranjape, BikshamGsujja, Vinod Goud, Shruti Vispute. (April 28, 2009) "Water Conflicts in India: Million Revolts in the Making." Economic and Political Weekly: http:/ / www.conflicts.indiawaterportal.org/?q=node/13\#TD.

Kalair, A. R. Abas, N. Kalair, E. \& Khan, N. (2019). Water, energy and food nexus of Indus water treaty: water governance. Water-Energy Nexus.

Khalid, Iram. (2018). Food Security: Understanding Pakistan's National Security Concerns. Journal of Political Studies, Special Issue, [online] 121:132. Available at: http://pu.edu.pk/images/journal/pols/pdf-files/10_spec_18.pdf [Accessed 14 Oct. 2019].

Khalid, Iram. \& Begum, I. (2013). Hydro Politics in Pakistan: Perceptions and Misperception. A Research Journal of South Asian Studies, Vol. 28, pp. 7-23.

Khalid, Iram. \& Khan, M. (2016). Water Scarcity- A Major Human Security Challenge to Pakistan. A Research Journal of South Asian Studies, Vol. 31, pp.525 - 539.

Kokab, R. U.\& Nawaz, A. (2013). Indus water treaty: need for review. Asian J SocSci, 2, 210-218.

Lynch, J. Maslin, M. Balzter, H. \& Sweeting, M. (2013). Sustainability: Choose satellites to monitor deforestation. Nature, 496(7445), 293.

Malik, John Briscoe \& R. P. S. (June 2008) "India's Water Economy: Bracing for a Turbulent Future. "Washington, DC: Water Sector Board of the Sustainable 
Development Network of the World Bank Group.NewDelhi:OxfordUniversityPress.http:// siteresources.worldbank.org/E XTWAT/Resources/46021221210008549997/PNOTE10_IndiaWater.pdf? (accessed July 28, 2019).

Mekonnen, M. M. \& Hoekstra, A. Y. (2016). Four billion people facing severe water scarcity. Science advances, 2(2), e1500323.

Paglia, L. (2018). WHO: healthy diet to prevent chronic diseases and caries. European journal of paediatric dentistry: official journal of European Academy of Paediatric Dentistry, 19(1), 5-5.

Parry, M. Arnell, N. McMichael, T. Nicholls, R. Martens, P. Kovats, S. Livermore, Rosenzweig, C. Iglesias, A. \& Fischer, G. (2001) Millions at risk: defining critical climate change threats and targets. Global Environmental Change 11: 181-183.

Pathak, D. Pramanik, P. Khanna, M. \& Kumar, A. (2014). Climate change and water availability in Indian agriculture: Impacts and adaptation. Indian Journal of Agricultural Sciences, [online] (84(6):671-679). Available at: https://www.researchgate.net/publication/263057821_Climate_change_and_w ater_availability_in_Indian_agriculture_Impacts_and_adaptation [Accessed 14 Oct. 2019].

Pongthanaisawan, J. \& Sorapipatana, C. (2013). Greenhouse gas emissions from Thailand's transport sector: Trends and mitigation options. Applied Energy, 101, 288-298.

Pradhan, T. \& Bhattacharya, K. (2019). Water Management, Water Politics and Rule of Law in India. International Journal of Civil Engineering and Technology, 10(3).

Reuters, (2019). U.S. Retrieved 11 October 2019, from https:/ / www.reuters.com/article/us-india-ganges/saving-a-river-pollution-inindias-holy-ganges-makes-it-toxic-idUSKCN1PC0CT

Salve, P. (2017). Hindustan Times. Retrieved 11 October 2019, from https:/ / www.hindustantimes.com/india-news/6-3-crore-indians-do-not-haveaccess-to-clean-drinking-water/story-dWIEyP962FnM8Mturbc52N.html

Scheuring, A. \& Engelbert, E. (2002). Water scarcity. Berkeley: Published by scholarship, the California Digital Library, the Regents of the University of California.

Sergiusz Prokurat. (2015). Drought and water shortages in Asia as a threat and economic problem: Journal of Modern Science, 235-250

Sinha, Rajesh. (Feb 18,2006) "Transboundary Disputes: Two Neighbours in a Treaty, Baglihar Project in Hot Waters." Economic and Political Weekly, Vol 41, Issue 7. 
http://www.conflicts.indiawaterportal.org/sites/conflicts.indiawaterportal.org /files/conflicts_bagl ihar.pdf.

US Government, (2019). Usgs.gov. Retrieved 11 October 2019, from https://www.usgs.gov/special-topic/water-science-school/science/how-muchwater-there-earth?qt-science_center_objects $=0 \# q t$-science_center_objects

Verma, R \& Sengupta, S. (2019). Downtoearth.org.in. Retrieved 11 October 2019, from https://www.downtoearth.org.in/news/water/india-has-20-river-basins-allover-exploited-65929

Wood, Christina. (1998). India - Water Resources Management Sector Review: initiating and sustaining water sector reforms. Sector Report, World Bank. 